\title{
Arginase promotes immune evasion of Echinococcus granulosus in mice
}

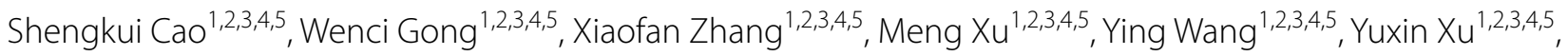 \\ Jianping Cao ${ }^{1,2,3,4,5}$, Yujuan Shen ${ }^{1,2,3,4,5^{*}}$ and Jiaxu Chen ${ }^{1,2,3,4,5^{*}}$
}

\begin{abstract}
Background: Cystic echinococcosis is a chronic disease caused by infection with the larvae of Echinococcus granulosus. The parasite's ability to establish persistent infection is partly due to its evolving immune evasion strategies. One strategy may involve the protective effect of arginase, which impedes the control of pathogens or tumors, whereas it remains largely unknown during E. granulosus infection. Here, we analyzed whether arginase was produced in peritoneal cells and assessed its role in immunosuppression in mice infected with protoscoleces of E. granulosus.
\end{abstract}

Methods: $B A L B / C$ mice injected with protoscoleces of E. granulosus were used to evaluate the expression of arginase (ARG) in mRNA and protein levels. The profiles of ARG-1 expression in peritoneal cells and CD3 3 expression in T cells from spleens were assessed at different time points (3, 6, 9 and 12 months post-infection) by flow cytometry. In vitro, peritoneal cells were co-cultured with purified $T$ cells in a transwell system, and the levels of $\mathrm{CD} 3 \zeta$ re-expression were compared by flow cytometry. Meanwhile, the changes of L-arginine and its related metabolites in serum were tested.

Results: Compared to the control group, the peritoneal cells from infected mice showed higher levels of ARG-1 mRNA and protein, unchanged ARG-2 and iNOS. Enhanced ARG-1 expression was present in SSC ${ }^{\text {low }} \mathrm{CD} 11 \mathrm{~b}^{+} \mathrm{F} 4 / 80^{+}$,

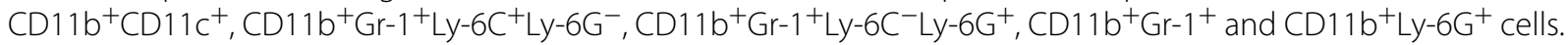
The proportion of cells and the proportion of ARG-1 expression in corresponding cells exhibited a rising trend along with the extension of infection time, except for fluctuations in SSClow $C D 11 b^{+} F 4 / 80^{+}$and $C D 11 b^{+} C D 11 c^{+}$cells at 12 months post-infection, whereas the expression of $\mathrm{CD} 3 \zeta$ chain in $\mathrm{CD}^{+}$and $\mathrm{CD} 8^{+} \mathrm{T}$ cells showed a descending trend. Purified T cells showed declined re-expression of $\mathrm{CD} 3 \zeta$ when co-cultured with peritoneal cells from infected mice, and $\mathrm{CD} 3 \zeta$ was regenerated by supplement of L-arginine or arginase inhibitor BEC, rather than NOS inhibitor L-NMMA or catalase. Meanwhile, the concentrations of L-arginine, L-citrulline and NO decreased, and those of L-ornithine and urea increased in serum post-infection.

Conclusions: Our findings demonstrated that ARG-1 expression is enhanced in multiple myeloid cells from peritoneum and promotes immune evasion of E. granulosus in mice by inhibiting the expression of T cell receptor CD3 $\zeta$ chain and antagonism against iNOS.

Keywords: Echinococcus granulosus, Arginase, Immunosuppression, INOS, Peritoneum

*Correspondence: shenyj@nipd.chinacdc.cn; chenjiaxu1962@163.com 1 National Institute of Parasitic Diseases, Chinese Center for Disease Control and Prevention, Shanghai 200025, China

Full list of author information is available at the end of the article

\section{Background}

Arginase is a ubiquitous and manganese-containing enzyme, including two isoforms: arginase-1 (ARG-1), localized in the cytosol; and arginase-2 (ARG-2), located in the mitochondria. During the urea cycle, the final reaction (converting $\mathrm{L}$-arginine to $\mathrm{L}$-ornithine and urea) is catalyzed by arginase, eliminating toxic ammonia [1]. 
However, excessively elevated arginase caused by infections or cancers could be detrimental for the host [2]. This mainly has two pathologically negative effects: (i) L-arginine starvation in vivo; and (ii) antagonism against nitric oxide (NO) synthase (NOS) for the same substrate (catalyzing L-arginine to L-citrulline and NO). The former could result in decreased expression of the T cell recep-

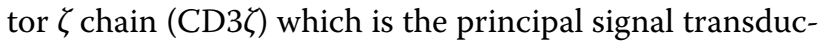
tion element of the receptor and an impairment in $\mathrm{T}$ cell function $[3,4]$, serving as a survival strategy for bacteria and parasites [5]. The latter reduces NO production which is antibacterial and beneficial to anti-tumor immunity [6]. NOS has three isoforms: neuronal NOS (nNOS); inducible NOS (iNOS); and endothelial NOS (eNOS). Among these, nNOS and eNOS are expressed constitutively, prevalent in neuronal tissue and endothelial cells, respectively, to produce $\mathrm{NO}$ at a low to moderate rate. iNOS is regulated at the expression level, present in various immune cells, and produces $\mathrm{NO}$ at a high rate $[7,8]$. iNOS-derived NO is needed for signal transduction and microbial defense. In addition to these immunoregulatory effects, ARG-1 expressed by myeloid cells has been involved in promoting tissue repair and wound healing because the $\mathrm{L}$-ornithine is a precursor of proline and polyamines $[9,10]$. However, in cutaneous leishmaniasis and some tumor models with high arginine-succinate synthetase (ASS1) activity which could produce L-arginine from citrulline, arginase seems to be dispensable for the long-term persistence to pathogens $[11,12]$. Here, we asked whether arginase was produced and whether its immunosuppression effect was present in Echinococcus granulosus-infected mice, although other immune evasion mechanisms have been found in previous studies $[13,14]$.

Echinococcus granulosus belongs to a platyhelminth cestode, whose larval stage is called a hydatid cyst and is filled with hydatid cyst fluid and protoscoleces (Eg-PSC). These larvae grow within intermediate hosts and cause cystic echinococcosis, commonly prevalent in pastoral regions around the world [15]. Although specific immune responses are present, E. granulosus infection persists in the host over many years [16]. It is largely because that the parasite's evasion strategies evolve to avoid being eliminated by the immune system.

Previously, we found accumulation of ARG-1 in monocytic myeloid-derived suppressor cells (M-MDSCs) from spleens [17] and Peng et al. [18] showed increased ARG-1 in macrophages from livers after E. granulosus infection. However, there is no report about the change of arginase in peritoneal cells in vivo and its immunosuppressive effect. Enterocoelia is one of the major pathogenic sites occupied with hydatid cysts, especially in the mouse model [15]. We analyzed the arginase expression profiles in multiple peritoneal myeloid cells and assessed its immunosuppression mechanism in the process of $E$. granulosus infection. Our results showed that elevated expression and activity of ARG-1, but not ARG-2, were present in multiple cells post-infection, along with declined expression of $\mathrm{T}$ cell receptor $\mathrm{CD} 3 \zeta$ chain in $\mathrm{CD} 4^{+}$and $\mathrm{CD} 8^{+} \mathrm{T}$ cells. Furthermore, the re-expression of $\mathrm{CD} 3 \zeta$ was inhibited by arginase in vitro, and ARG-1 antagonized iNOS in vivo. These observations revealed an immunoregulatory mechanism by which $E$. granulosus evades damage from the host.

\section{Methods}

\section{Mice, parasites and modeling}

Female BALB/c mice (aged 6-8 weeks) were purchased from SLAC Laboratory Animal Co. Ltd., Shanghai, China, under aseptic conditions. The Eg-PSC were obtained by puncturing the fertile hydatid cysts within livers of naturally infected sheep from Xinjiang Uygur Autonomous Region, China. The parasites were washed five times using a sterile $0.9 \% \mathrm{NaCl}$ solution supplemented with $100 \mathrm{U} / \mathrm{ml}$ penicillin and $100 \mu \mathrm{g} / \mathrm{ml}$ streptomycin. The vitality of PSC from each individual liver was determined by the trypan blue dye exclusion method and those exhibiting over $90 \%$ vitality were used for infection.

Fifty $\mathrm{BALB} / \mathrm{c}$ mice were intraperitoneally inoculated with a $200 \mu \mathrm{l}$ sterile suspension containing 2000 live EgPSC in $0.9 \% \mathrm{NaCl}$, and fifty controls were inoculated with $200 \mu \mathrm{l} 0.9 \% \mathrm{NaCl}$. All mice were maintained in specific pathogen-free conditions and fed with standard laboratory food and water.

Genotype identification of Eg-PSC was carried out according to Nakao et al. [19] using the primers (5'-TTG AAT TTG CCA CGT TTG AAT GC- $3^{\prime}$ and $5^{\prime}$-GAA CCT AAC GAC ATA ACA TAA TGA-3') targeting cytochrome $c$ oxidase subunit 1 gene.

\section{Western blot analysis}

Peritoneal cells were isolated immediately after the infected and control mice were sacrificed under sterile conditions 9 months post-infection. Macrophages were separated using a Macrophage Isolation Kit (Peritoneum) (Miltenyi Biotec, Bergisch Gladbach, Germany) and the purity $\left(\mathrm{F} 4 / 80^{+}\right)$exceeded $90 \%$, as determined by flow cytometry. Macrophages and non-macrophage cells were respectively lysed for $30 \mathrm{~min}$ on ice in a RIPA solution containing protease inhibitors. Lysates were then separated by $10 \%$ SDS-PAGE and transferred to a polyvinylidene difluoride membrane (Merck Millipore, Darmstadt, Germany). After blocking of non-specific binding sites, the respective blots were incubated with different primary antibodies [anti-Arginase-1, anti-Arginase-2, anti-iNOS and anti- $\beta$-actin (Cell Signaling Technology, 
Danvers, MA, USA)] and the respective HRP-conjugated secondary antibodies. The results were visualized using the ECL detection system (Merck Millipore) and recorded with a Universal Hood II Imager (Bio-Rad, California, USA). Band intensities were evaluated using image J (NIH, Bethesda, MD, USA).

\section{Immunofluorescent assay}

Peritoneal cells were cultured in a Millicell EZ Slide (Merck Millipore) for $48 \mathrm{~h}$. Cells which grew in the slide were fixed, rinsed and stained using anti-Arginase- 1 antibody and anti-Arginase- 2 antibody, respectively (Cell Signaling Technology). After washing with PBS, the slides were incubated with a secondary antibody conjugated with fluorescein (Life Technologies, Carlsbad, CA, USA). For visualizing nuclei, the slides were mounted with DAPI (Cell Signaling Technology). Images were captured with a fluorescence microscope (Leica DM IRB, Germany).

Reverse transcription quantitative reaL-time PCR (RT-qPCR) Total RNA in peritoneal cells was extracted using a TRIzol reagent (Life Technologies) and immediately reverse transcribed into cDNA using the PrimeScript ${ }^{\mathrm{TM}}$ RT reagent kit (Takara, Kusatsu, SG, Japan). The cDNA was amplified in qPCR reactions containing TB Green Premix Ex Taq (Takara) with $0.4 \mu \mathrm{M}$ primers on a BioRad CFX96 system. The thermal cycler conditions were as follows: 5 min denaturation at $95{ }^{\circ} \mathrm{C}$, followed by 40 cycles of $30 \mathrm{~s}$ at $95{ }^{\circ} \mathrm{C}, 30 \mathrm{~s}$ at $55^{\circ} \mathrm{C}$, and $30 \mathrm{~s}$ at $72{ }^{\circ} \mathrm{C}$. The primers used for $\mathrm{qPCR}$ are shown in Additional file 1: Table S1. Relative mRNA expression was calculated by comparative quantification cycle $(\mathrm{Cq})$ normalized to GAPDH using the $2^{-\Delta \Delta C q}$ method.

\section{Arginase activity assay}

Arginase activity from peritoneal cells was tested by a commercial Arginase Activity Colorimetric Assay Kit (BioVision, Milpitas, CA, USA) according to the manufacturer's specifications. Briefly, $2 \times 10^{6}$ cells were lysed on ice with $200 \mu \mathrm{l}$ ice cold arginase assay buffer. After centrifugation at $10,000 \times g$ for $5 \mathrm{~min}$, the supernatant was collected and centrifuged at $15,000 \times g$ for 2 min using a $10 \mathrm{kDa}$ spin column to remove urea from the samples. The filtrate was discarded and the sample (retentate) was brought to its original volume with arginase assay buffer, then intermediately quantified. The unit of arginase activity was denoted as $\mathrm{U} / \mathrm{ml}$ (one unit means the amount of enzyme that will generate $1.0 \mu \mathrm{mol}$ of $\mathrm{H}_{2} \mathrm{O}_{2}$ per min at $37^{\circ} \mathrm{C}$ ).

\section{T cell isolation and stimulation}

Spleens were isolated from control BALB/c mice under aseptic conditions and prepared for cellular suspensions through a $70 \mu \mathrm{m}$ cell strainer (BD Biosciences, San Jose, CA, USA). Single-cell suspensions were resuspended in an erythrocyte-lysing buffer (BD Biosciences) and washed. $T$ cells were enriched by a Pan $T$ Cell Isolation Kit (Miltenyi Biotec) according to the manufacturer's specifications. The purity $\left(\mathrm{CD}^{2} \varepsilon^{+}\right)$was confirmed at $>90 \%$ by flow cytometry. Normal $\mathrm{T}$ cells were stimulated with $3 \mu \mathrm{g} / \mathrm{ml}$ anti-CD3e plus $500 \mathrm{ng} / \mathrm{ml}$ anti-CD28 antibodies (BD Biosciences) and cultured in RPMI 1640 (Life Technologies) without $\mathrm{L}$-arginine for $24 \mathrm{~h}$. Media was supplemented with $4 \%$ fetal bovine serum (Gibco, Carlsbad, CA, USA), $100 \mathrm{U} / \mathrm{ml}$ penicillin and $100 \mu \mathrm{g} / \mathrm{ml}$ streptomycin.

\section{Co-culture in transwells}

Peritoneal cells from E. granulosus-infected and homochronous control mice ( 9 months post-infection) were respectively cultured in the bottom chamber of a twelvewell transwell system containing $0.4 \mu \mathrm{m}$ pores (Corning, New York, USA). RPMI culture medium was the same as described above, but contained $300 \mu \mathrm{M}$ L-arginine (Sigma-Aldrich, Saint Louis, MO, USA). In some experiments, an excess of $\mathrm{L}$-arginine $(2 \mathrm{mM})$, the arginase inhibitor BEC $(90 \mu \mathrm{M}$, BioVision), the NOS inhibitor L-NMMA (500 $\mu \mathrm{M}$, BioVision) and hydrogen peroxide $\left(\mathrm{H}_{2} \mathrm{O}_{2}\right)$ scavenger catalase (200 U/ml, Sigma-Aldrich) were respectively added in the cultures at $0 \mathrm{~h}$. After 24 $\mathrm{h}$, stimulated $\mathrm{T}$ cells in the absence of $\mathrm{L}$-arginine were transferred to the upper chamber of transwells. The reexpression of $\mathrm{CD} 3 \zeta$ in $\mathrm{CD} 4^{+}$and $\mathrm{CD} 8^{+} \mathrm{T}$ cells was tested after $48 \mathrm{~h}$ by flow cytometry.

\section{Flow cytometry analysis}

Single-cell suspensions were prepared from the upper chamber of transwells and spleens of E. granulosusinfected and homochronous control mice at different time points. To assess the differential expression of $\mathrm{CD} 3 \zeta$ in $\mathrm{CD}^{+}$and $\mathrm{CD}^{+} \mathrm{T}$ cells, surface staining was performed using Brilliant Violet 421 labeled anti-CD3e, APC labeled anti-CD4 and PE labeled anti-CD8 (BD Biosciences). After cells were fixed and permeabilized by a Cytofix/Cytoperm ${ }^{\text {TM }}$ Fixation/Permeabilization Kit (BD Biosciences), intracellular staining was performed with AF488 labeled anti-CD3 $\zeta$ and isotypic control (Santa Cruz Biotechnology, Santa Cruz, CA, USA).

In addition, to assess the differential expression of ARG-1 from multiple peritoneal myeloid cells in vivo (3, 6, 9 and 12 months post-E. granulosus infection), surface staining was performed using Brilliant Violet 421 labeled anti-CD11b, APC labeled anti-Gr-1, FITC labeled anti-Ly-6G, FITC labeled anti-F4/80, PE-Cy7 labeled anti-Ly-6C and PE-Cy7 labeled anti-CD11c (BD Biosciences). Intracellular staining was performed with $\mathrm{PE}$ 
labeled anti-arginase- 1 and isotypic control (Life Technologies). The percentages of $\mathrm{SSC}^{\text {high }} \mathrm{CD} 11 \mathrm{~b}^{+} \mathrm{F} 4 / 80^{+}$cells in total peritoneal leukocytes, $\mathrm{SSC}^{\text {low }} \mathrm{CD} 11 \mathrm{~b}^{+} \mathrm{F} 4 / 80^{+}$, $\mathrm{CD}_{11} \mathrm{~b}^{+} \mathrm{CD} 11 \mathrm{c}^{+}, \mathrm{CD} 11 \mathrm{~b}^{+} \mathrm{Gr}-1^{+} \mathrm{Ly}-6 \mathrm{C}^{+} \mathrm{Ly}-6 \mathrm{G}^{-}, \mathrm{CD} 11 \mathrm{~b}^{+}$ Gr- $1^{+}$Ly- $6 \mathrm{C}^{-} \mathrm{Ly}-6 \mathrm{G}^{+}, \mathrm{CD} 11 \mathrm{~b}^{+} \mathrm{Gr}-1^{+}$and $\mathrm{CD} 11 \mathrm{~b}^{+} \mathrm{Ly}-6 \mathrm{G}^{+}$ cells in SSC-low leukocytes, together with the percentage of ARG-1 expression in corresponding cells were determined.

Fluorescence acquisition was determined using the LSRFortessa X-20 flow cytometer (BD Biosciences) and data analysis was performed using Flowjo software (BD Biosciences). Results were expressed as mean fluorescence intensity or percentage.

\section{Measurement of circulating free arginine, ornithine, citrulline, urea and NO}

A $200 \mu \mathrm{l}$ serum sample was thoroughly mixed with a $200 \mu \mathrm{l}$ mixture of $0.1 \mathrm{~mol} / 1 \mathrm{HCl}$ and $10 \%$ trichloracetic acid (1:2). The solution was centrifuged at $12,000 \times \mathrm{rpm}$ for $25 \mathrm{~min}$, then the supernatant was collected and standing at $4{ }^{\circ} \mathrm{C}$ for $30 \mathrm{~min}$. After a second centrifugation $(12,000 \times \mathrm{rpm}$ for $25 \mathrm{~min}$ ), the supernatant was collected and the presence of arginine, ornithine, citrulline and urea was determined using an ion-exchange AA analyzer (L-8900, High speed amino-acid Auto-Analyzer; Hitachi, Tokyo, Japan).

The production of NO in serum was measured using the Nitric Oxide Fluorometric Assay Kit (BioVision) according to the manufacturer's instructions. The total concentration of nitrite is used as a quantitative measure of NO production that is completely converted to nitrite.

\section{Statistical analysis}

Comparisons of arginase expression and activity, CD3 $\zeta$ expression, concentrations of arginine, ornithine, citrulline, urea and NO were performed via a one-way or twoway ANOVA, or a two-tailed Student's t-test using the GraphPad Prism statistical programs (GraphPad Software, San Diego, CA, USA). Data were represented as the mean \pm standard deviation (SD). A $P$-value $<0.05$ was considered statistically significant.

\section{Results}

\section{Genotype identification}

Comparative analysis using nucleotide sequences deposited in the GenBank database, the Eg-PSC used for infection in the present study was identified as genotype G1.

\section{ARG-1 was upregulated in multiple peritoneal cells post-infection in vivo}

To confirm the differential expression of arginase in peritoneal cells in vivo, a western blot analysis, immunofluorescent assay and RT-qPCR were used to determine the expression level in mice infected with Eg-PSC and homochronous control mice (9 months post-infection). Considering that macrophages make up the majority of peritoneal cells, macrophages and non-macrophage cells were detected, respectively, for arginase and iNOS by western blot analysis. Enhanced ARG-1 expression (protein level) was observed in macrophages and nonmacrophage cells from infected mice compared with that in the control group $\left(F_{(6,14)}=2272, P<0.001\right)$, whereas the expression of ARG-2 and iNOS were unchanged (Fig. 1a). In wild-type control mice, ARG-1 was mainly present in macrophages. The immunofluorescent assay for whole peritoneal cells also confirmed increased ARG-1 expression in infected mice compared with that in control mice (Fig. 1b), while the ARG-2 expression remained unchanged (Additional file 2: Figure S1). RTqPCR results exhibited enhanced $A R G-1\left(F_{(2,6)}=683.6\right.$, $P<0.001)$, unchanged $A R G-2$ and $i N O S$ mRNA levels in infected mice compared with those in control mice (Fig. 1c). Meanwhile, higher arginase activity was found in peritoneal cells from infected mice than that in the control group $\left(t_{(4)}=3.367, P=0.019\right)$ (Fig. 1d).

To further characterize the population producing ARG-1 in peritoneal cells, flow cytometry analysis was performed for multiple myeloid cells at different time points post-infection (3, 6, 9 and 12 months). Enhanced expression of ARG-1 was found in $\mathrm{SSC}^{\mathrm{low}} \mathrm{CD} 11 \mathrm{~b}^{+} \mathrm{F} 4 / 80^{+}$,

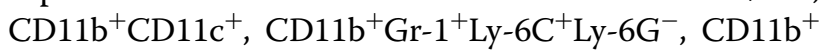
Gr- ${ }^{+} \mathrm{Ly}-6 \mathrm{C}^{-} \mathrm{Ly}-6 \mathrm{G}^{+}, \mathrm{CD} 11 \mathrm{~b}^{+} \mathrm{Gr}-1^{+}$and $\mathrm{CD} 11 \mathrm{~b}^{+} \mathrm{Ly}-6 \mathrm{G}^{+}$ cells in infected mice compared with that in control mice (Fig. 2b, d). Compared to that at 3 months post-infection, increased expression of ARG-1 was

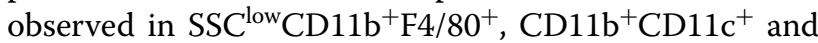
CD $11 b^{+} \mathrm{Gr}-1^{+} \mathrm{Ly}-6 \mathrm{C}^{-} \mathrm{Ly}-6 \mathrm{G}^{+}$cells from infected mice at 6 months $\left(F_{(3,12)}=3.963, P<0.001 ; F_{(3,12)}=26.29, P<0.001\right.$; and $F_{(3,12)}=16.46, P<0.001$, respectively). Compared to those at 6 months post-infection, $\mathrm{SSC}^{\text {high }} \mathrm{CD} 11 \mathrm{~b}^{+} \mathrm{F} 4 / 80^{+}$,

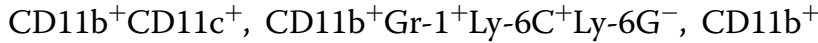
Gr- $1^{+} \mathrm{Ly}-6 \mathrm{C}^{-} \mathrm{Ly}-6 \mathrm{G}^{+}$and $\mathrm{CD} 11 \mathrm{~b}^{+} \mathrm{Ly}-6 \mathrm{G}^{+}$cells from infected mice exhibited an enhanced percentage of ARG-1 expression at 9 months $\left(F_{(3,12)}=1.209, P<0.001 ; F_{(3,12)}\right.$ $=26.29, P=0.002 ; F_{(3,12)}=17.48, P<0.001 ; F_{(3,12)}=16.46$, $P=0.007$; and $F_{(3,12)}=12.44, P=0.003$, respectively). A decreased level of ARG-1 expression was found in $\mathrm{SSC}^{\text {low }} \mathrm{CD} 11 \mathrm{~b}^{+} \mathrm{F} 4 / 80^{+}$and $\mathrm{CD} 11 \mathrm{~b}^{+} \mathrm{CD} 11 \mathrm{c}^{+}$cells from infected mice at 12 months compared to that at 9 months post-infection $\left(F_{(3,12)}=3.963, \quad P=0.002\right.$ and $F_{(3,12)}$ $=26.29, P<0.001$, respectively). In addition, in infected mice, the percentages of $\mathrm{SSC}^{\text {high }} \mathrm{CD} 11 \mathrm{~b}^{+} \mathrm{F} 4 / 80^{+}$cells in total peritoneal leukocytes, $\mathrm{SSC}^{\text {low }} \mathrm{CD} 11 \mathrm{~b}^{+} \mathrm{F} 4 / 80^{+}$,

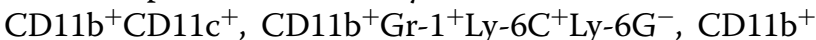
Gr- ${ }^{+}$Ly- $6 \mathrm{C}^{-} \mathrm{Ly}-6 \mathrm{G}^{+}, \mathrm{CD} 11 \mathrm{~b}^{+} \mathrm{Gr}-1^{+}$and CD $11 \mathrm{~b}^{+} \mathrm{Ly}-6 \mathrm{G}^{+}$ cells in SSC-low leukocytes, exhibited a rising trend along with the extension of infection time, except for a slight 


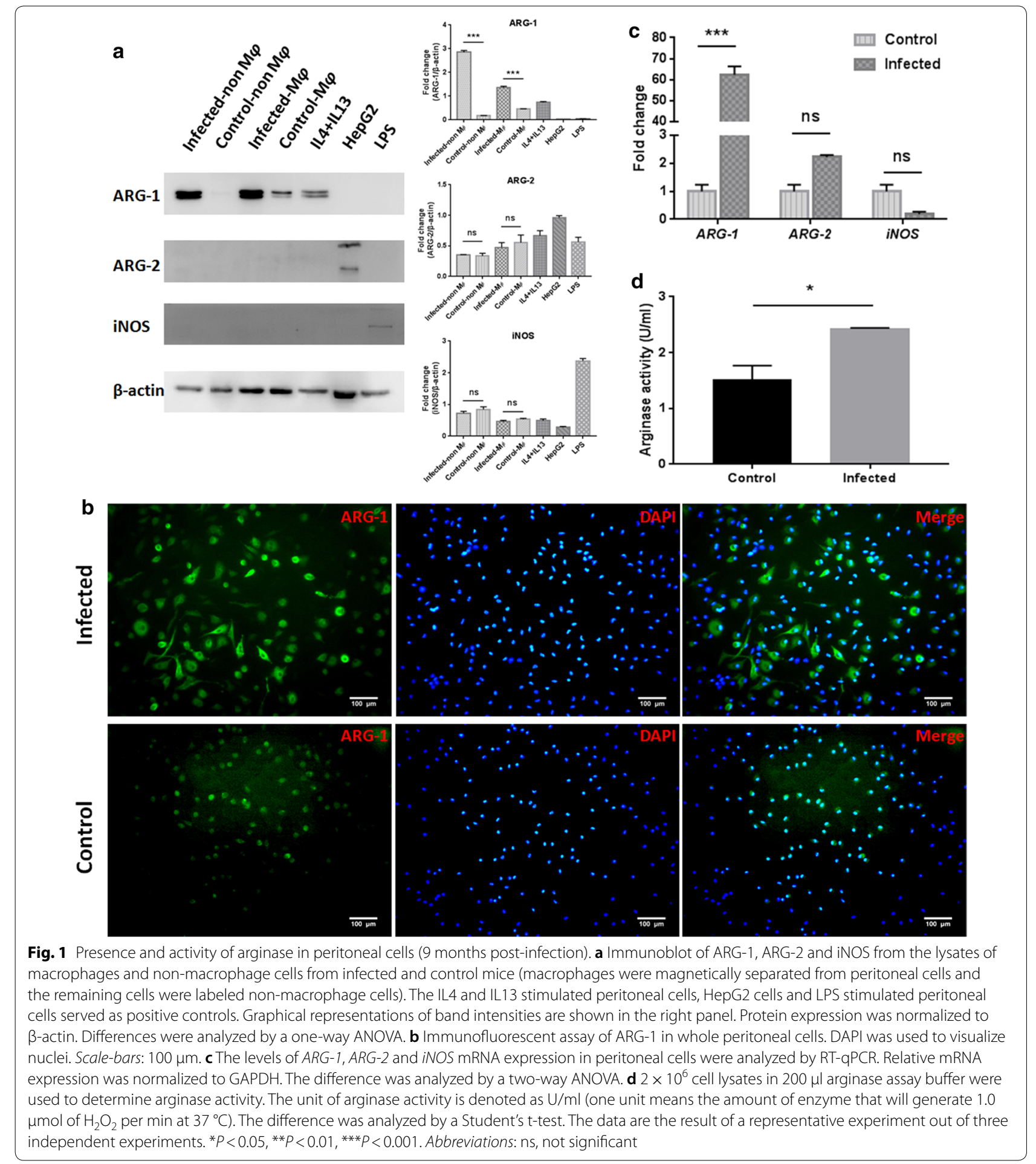

fluctuation in $\mathrm{SSC}^{\mathrm{low}} \mathrm{CD} 11 \mathrm{~b}^{+} \mathrm{F} 4 / 80^{+}$cells at 12 months post-infection. Taken together, these data verified that ARG-1 is upregulated in multiple peritoneal cells after EgPSC infection and exhibits a gradually rising trend prior to 9 months.

\section{$\mathrm{CD} 3 \zeta$ was downregulated in $\mathrm{CD} 4^{+}$and $\mathrm{CD} 8^{+} \mathrm{T}$ cells after 9 months post-infection in vivo}

After 3, 6, 9 and 12 months post-infection, mice (including the homochronous control mice) were respectively sacrificed to determine differential expression of $\mathrm{CD} 3 \zeta$ 


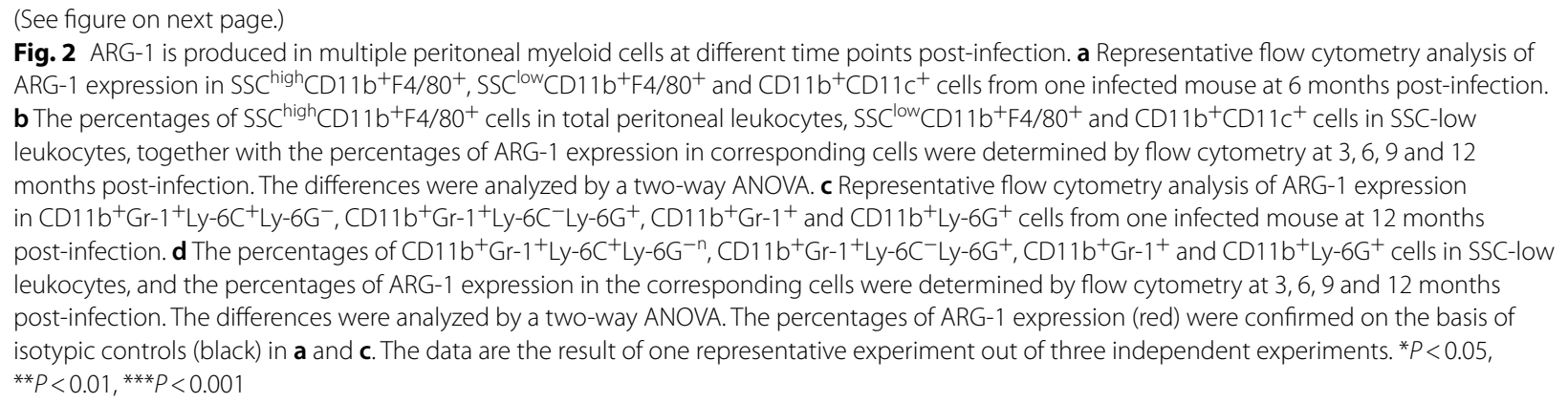

in $\mathrm{CD}^{+}$and $\mathrm{CD} 8^{+} \mathrm{T}$ cells from spleens. Kinetic studies showed that the relative expression of $\mathrm{CD} 3 \zeta$ remained unchanged in $\mathrm{CD} 4^{+}$and $\mathrm{CD} 8^{+} \mathrm{T}$ cells during the first 6 months after Eg-PSC infection, and the decline occurred at 9 and 12 months in the infected group compared to the control group $\left(F_{(3,12)}=94.88, P<0.001\right.$ and $F_{(3,12)}=75.54$, $P<0.001$, respectively) (Fig. 3 ).

\section{Arginase blocked $\mathrm{CD} 3 \zeta$ re-expression in activated $\mathrm{T}$ cells in vitro}

In conventional RPMI 1640 media containing L-arginine, $\mathrm{T}$ cells stimulated with anti-CD $3 \varepsilon^{+}$and anti$\mathrm{CD}_{28}{ }^{+}$antibodies undergo a cycle of internalization and re-expression of $\mathrm{CD} 3 \zeta$. However, this will be blocked in the absence of L-arginine, preventing the assembly of new $\mathrm{T}$ cell receptors [20]. To confirm the role of arginase involved in immunosuppression due to Eg-PSC infection, freshly isolated peritoneal cells from infected or control mice were co-cultured with activated $\mathrm{T}$ cells in a transwell system. When compared to the control group, an ability of $\mathrm{CD} 4^{+}$and $\mathrm{CD}^{+} \mathrm{T}$ cells to re-express $\mathrm{CD} 3 \zeta$ was blocked in the Eg-PSC-infected group $\left(F_{(5,12)}=27.52, P<0.001\right.$ and $F_{(5,12)}=23.16$, $P<0.001$, respectively). Nevertheless, this effect was prevented by the excess exogenous $\mathrm{L}$-arginine and the arginase inhibitor BEC (for CD4 $4^{+} \mathrm{T}$ cells: $F_{(5,12)}=27.52$, $P<0.001$ and $P=0.007$; for $\mathrm{CD} 8^{+} \mathrm{T}$ cells: $F_{(5,12)}=23.16$, $P<0.001$ and $P=0.035$ ), but not by the addition of the NOS inhibitor L-NMMA nor the hydrogen peroxide scavenger catalase, demonstrating that the depletion of L-arginine by arginase from E. granulosus-associated peritoneal cells impaired the re-expression of $\mathrm{T}$ cell receptor $\mathrm{CD} 3 \zeta$ chain (Fig. 4).

\section{L-arginine metabolism was skewed toward a preferential urea/ornithine production}

To validate the systematic changes of L-arginine and its related metabolites in serum, the concentrations of amino acids, urea and NO were assessed in a quantitative profiling between Eg-PSC-infected mice $(n=8)$ and controls $(n=8) 9$ months post-infection. The concentration of L-arginine was significantly decreased in the infected group (less than $50 \mu \mathrm{M}$ ) compared with that in the control group $\left(t_{(14)}=7.581, P<0.001\right)$. Meanwhile, a decreased concentration of citrulline and $\mathrm{NO}$, and an increased concentration of urea and ornithine were observed in the infected group $\left(t_{(14)}=2.711\right.$, $P=0.017 ; t_{(14)}=9.781, P<0.001 ; t_{(14)}=4.059, P=0.001$; and $t_{(14)}=3.302, P=0.005$, respectively), consistent with elevated urea/arginine ratio, citrulline/arginine ratio, ornithine/arginine ratio and decreased arginine/(citrulline + ornithine) ratio (Fig. 5). These results verified that $\mathrm{L}$-arginine metabolism in Eg-PSC-infected mice is skewed toward a preferential urea/ornithine production, in agreement with elevated arginase expression and activity in vivo.

\section{Discussion}

One of the hallmarks during parasite infection is persistence. Previous studies have revealed that the hydatid cysts survival in hosts is prolonged by complex evasion mechanisms, such as physical and immunological protection by the laminated layer [21], blocking the penetration of IgG by the germinal layer [22], modulation by antigenpresentation cells, antigen $B$ and cytokines [23]. The present study supports that ARG-1 is also involved in immunosuppression in mice infected with $E$. granulosus.

The impact of ARG-1 and ARG-2 on pathogen control, host survival and immune response has been studied in several parasitoses. For example, during murine Toxoplasma gondii infection, ARG-1 in macrophages thwarted effective immunity, impaired parasite control, and elimination of ARG-1 favored host survival [24]. On the contrary, in infections with the Trichuris muris or Leishmania major, mice lacking ARG-1 or ARG-2 showed unaltered cytokine responses, parasite burden and NO production [11, 25]. Here, our data showed elevated expression (protein and mRNA levels) and activity of ARG-1 in peritoneal cells from mice with E. granulosus infection. Nevertheless, ARG-2 and 


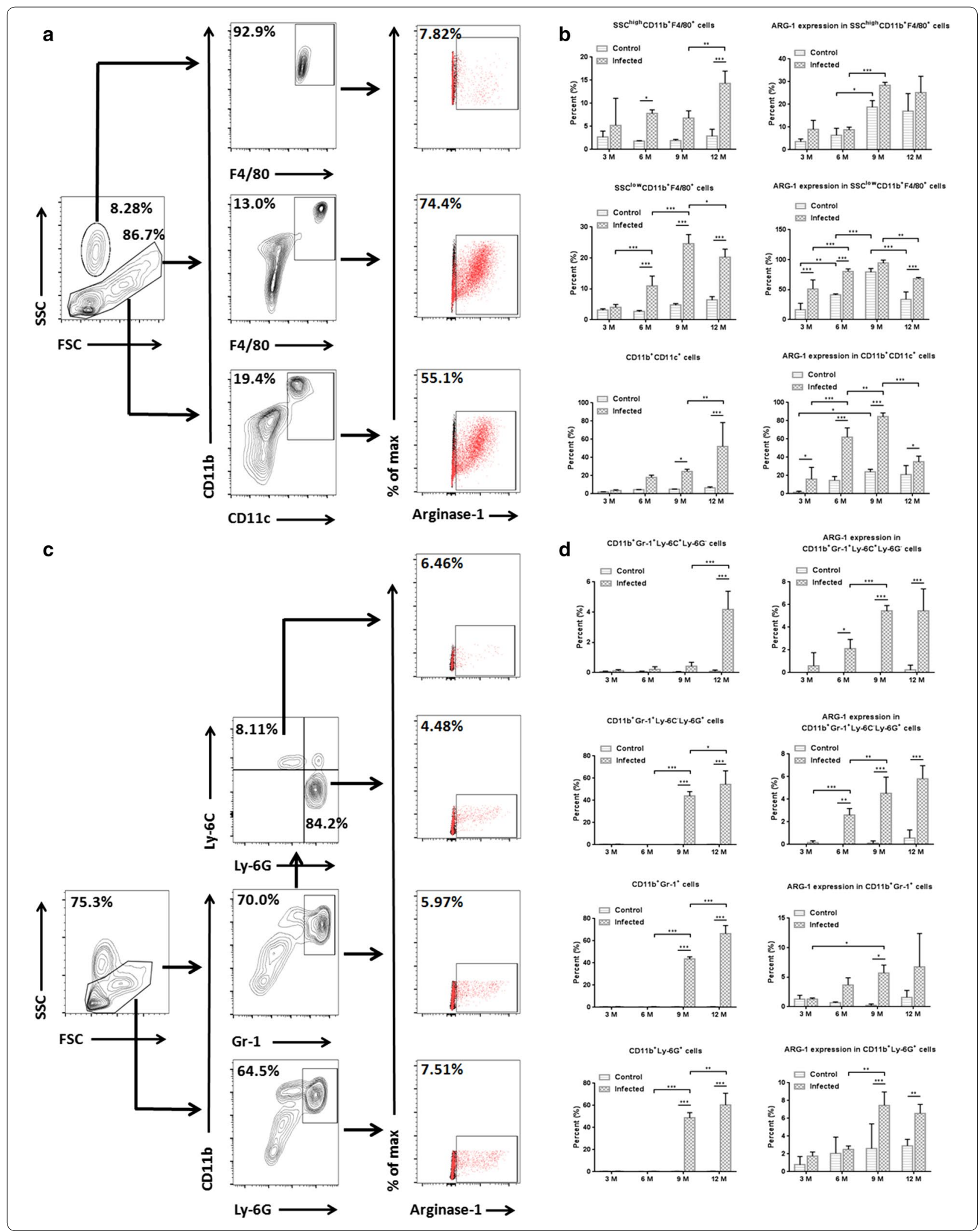



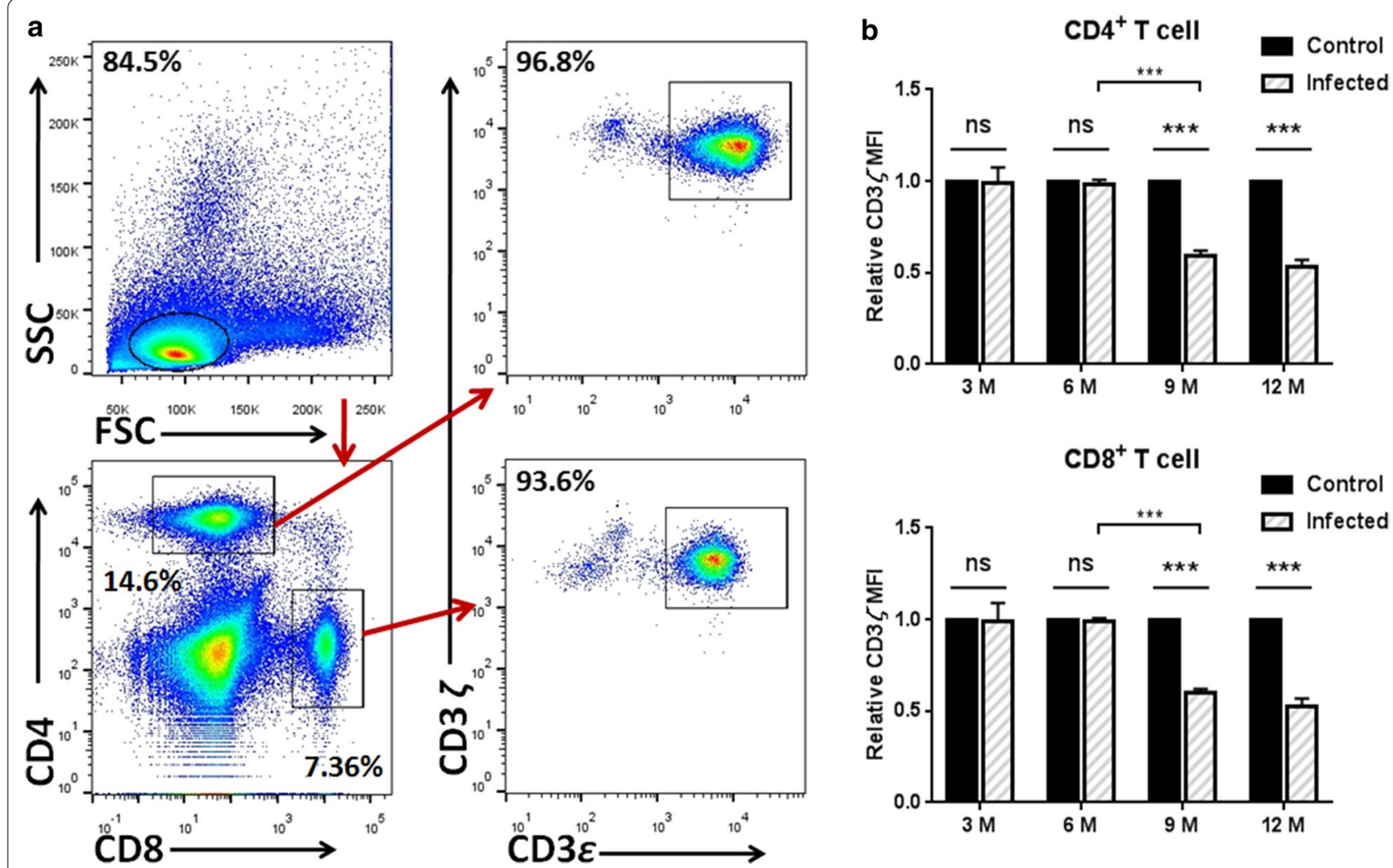

Fig. 3 Dynamic studies of $\mathrm{CD} 3 \zeta$ expression in $\mathrm{CD} 4^{+}$and $\mathrm{CD} 8^{+} \mathrm{T}$ cells in vivo. a Representative flow cytometry analysis of $\mathrm{CD} 3 \zeta$ expression in $\mathrm{CD} 4^{+}$ $\left(\mathrm{CD} 3 \varepsilon^{+} \mathrm{CD}^{+}\right)$and $\mathrm{CD}^{+}\left(\mathrm{CD} 3 \varepsilon^{+} \mathrm{CD} 8^{+}\right) \mathrm{T}$ cells among spleen leukocytes from one infected mouse at 6 months post-infection. $\mathbf{b}$ The relative MFI of $\mathrm{CD} 3 \zeta$ expression in $\mathrm{CD}^{+}$and $\mathrm{CD} 8^{+} \mathrm{T}$ cells was quantified by flow cytometry at different time points post-infection $(3,6,9$ and 12 months). The differences were analyzed by a two-way ANOVA. The data are the result of one representative experiment out of three independent experiments. ${ }^{*} P<0.05,{ }^{* *} P<0.01,{ }^{* * *} P<0.001$. Abbreviations: ns, not significant

iNOS were unchanged. Similarly, only ARG-1 was found in abnormal spleens and livers from E. granulosus-infected mice, as described in previous studies [17, 18]. Moreover, compared with the control mice, the fold change of ARG-1 expression in non-macrophage cells from infected mice increased more than that in macrophages, due to high level of ARG-1 expression in macrophages from control mice as shown in Figs. 1a, $2 \mathrm{~b}\left(\mathrm{~F} 4 / 80^{+}\right)$. Flow cytometry analysis detected enhanced production of ARG- 1 in $\mathrm{SSC}^{\mathrm{low}} \mathrm{CD} 11 \mathrm{~b}^{+} \mathrm{F} 4 / 80^{+}$, $\mathrm{CD}_{11} \mathrm{~b}^{+} \mathrm{CD} 11 \mathrm{c}^{+}, \quad \mathrm{CD} 11 \mathrm{~b}^{+} \mathrm{Gr}-1^{+} \mathrm{Ly}-6 \mathrm{C}^{+} \mathrm{Ly}-6 \mathrm{G}^{-}$, CD $11 b^{+}$Gr- $1^{+}$Ly- $6 C^{-}$Ly- $6 G^{+}, \quad$ CD $11 b^{+}$Gr- $1^{+}$and CD11b ${ }^{+}$Ly- $6 \mathrm{G}^{+}$cells, but no significant change in $\mathrm{SSC}^{\text {high }} \mathrm{CD} 11 \mathrm{~b}^{+} \mathrm{F} 4 / 80^{+}$cells from infected mice compared with that in control mice. Elevated arginase expression was consistently found in macrophages, dendritic cells, granulocytes and immature myeloid cells (myeloid suppressor cells) under other models or stimuli, depleting L-arginine [26-28].

The active and inactive stages of hydatid disease are dominated by different immune responses. Th1 response benefits the host, facilitating the death and clearance of Eg-PSC in mice, whereas Th2 response benefits the parasite, allowing it to survive in the host [29]. In patients with cystic echinococcosis, antigen $B$ has been shown to impair the Th1 response by upregulating Th2 cytokines IL-4 and IL-13 which could stimulate ARG-1 production in vitro [30, 31]. For Eg-PSC-infected mice, the Th1type cytokine profile was predominant at the early phase (3-4 weeks post-infection), in the 4th week this shifted to a Th2-type cytokine profile [32]. In the chronic phase, we found that the expression of ARG-1 exhibits a rising trend in multiple peritoneal myeloid cells along with the extension of infection time, except for fluctuations in $\mathrm{SSC}^{\text {low }} \mathrm{CD} 11 \mathrm{~b}^{+} \mathrm{F} 4 / 80^{+}$and $\mathrm{CD} 11 \mathrm{~b}^{+} \mathrm{CD} 11 \mathrm{c}^{+}$cells at 12 months post-infection.

The suppressive activity of arginase has mainly been correlated with L-arginine depletion, which leads to downregulation of $\mathrm{T}$ cell receptor $\mathrm{CD} 3 \zeta$ chain expression in many diseases [33-35]. However, some tumors with high ASS1 activity are able to produce L-arginine from citrulline and are not affected by the high level of arginase 
$\mathrm{CD4}^{+} \mathrm{T}$ cell
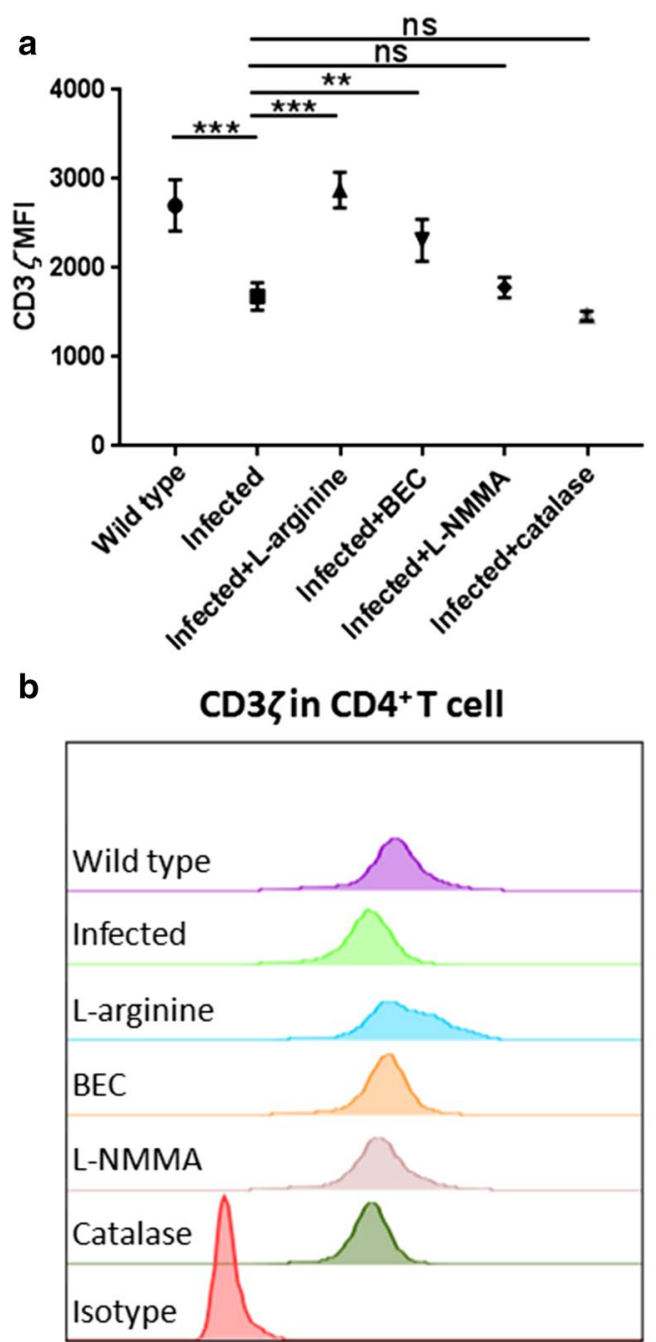

CD8 ${ }^{+} \mathrm{T}$ cell

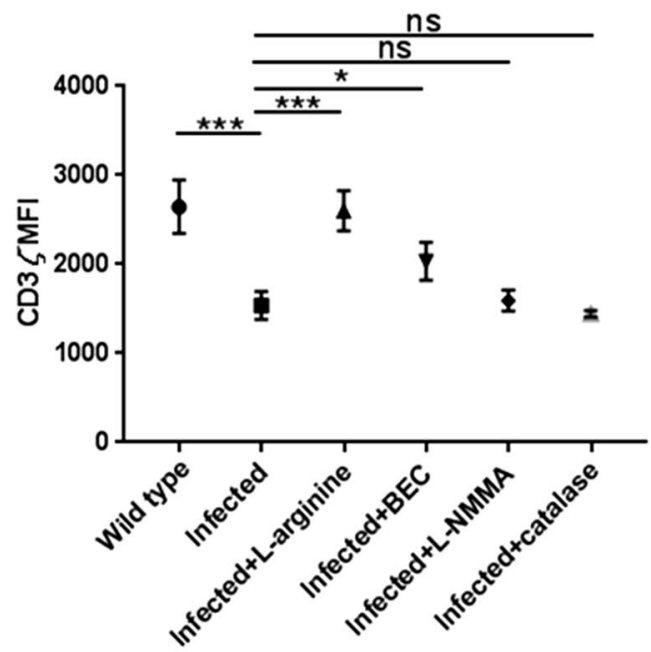

CD3 $\zeta$ in CD8 $+T$ cell

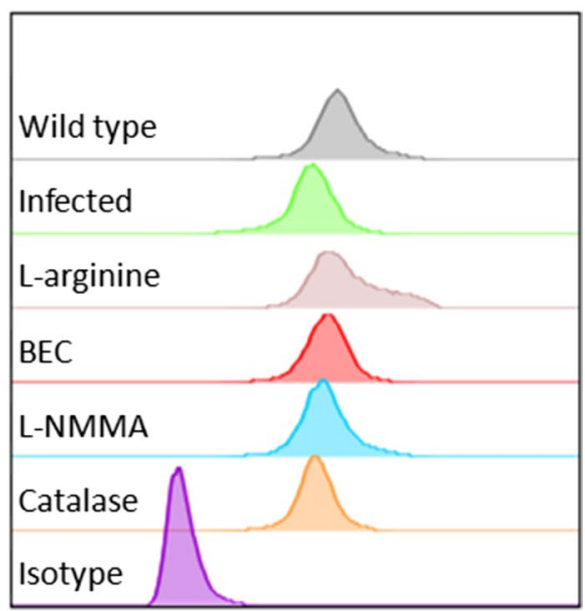

Fig. 4 Arginase produced by peritoneal cells from infected mice prevents the re-expression of the $\mathrm{CD} 3 \zeta$ chain. Isolated murine pan $T$ cells were stimulated with $3 \mathrm{\mu g} / \mathrm{ml}$ anti-CD3 p plus $500 \mathrm{ng} / \mathrm{ml}$ anti-CD28 antibodies in L-arginine-free RPMl 1640 for $24 \mathrm{~h}$, and peritoneal cells from infected/control mice were cultured in RPMI 1640 containing $300 \mu \mathrm{M} \mathrm{L-arginine} \mathrm{separately} \mathrm{for} 24 \mathrm{~h}$. Stimulated T cells were then added to the upper chamber of a co-culture transwell system containing the peritoneal cells in the bottom chamber for an additional $48 \mathrm{~h}$ of culture. In some experiments, the L-arginine $(2 \mathrm{mM}), \mathrm{BEC}(90 \mu \mathrm{MM}), \mathrm{L}-\mathrm{NMMA}(500 \mu \mathrm{M})$ and catalase $(200 \mathrm{U} / \mathrm{ml})$ were respectively added into the cultures at $0 \mathrm{~h}$. $\mathbf{a}$ $\mathrm{CD} 3 \zeta$ re-expression in $\mathrm{CD}^{+}$and $\mathrm{CD} 8^{+} \mathrm{T}$ cells was tested by flow cytometry. The differences were analyzed by a one-way ANOVA. $\mathbf{b}$ Representative histograms of $\mathrm{CD} 3 \zeta$ re-expression in activated $\mathrm{CD} 4^{+}$and $\mathrm{CD} 8^{+} \mathrm{T}$ cells co-cultured with peritoneal cells for $48 \mathrm{~h}$. The data are the result of one representative experiment out of three independent experiments. ${ }^{*} P<0.05$, ${ }^{* *} P<0.01,{ }^{* * *} P<0.001$. Abbreviations: ns, not significant

[12]. In the present study, we showed that the relative expression of $\mathrm{CD} 3 \zeta$ chain in $\mathrm{CD} 4^{+}$and $\mathrm{CD} 8^{+} \mathrm{T}$ cells decreased at 9 and 12 months after E. granulosus infection compared with that in the control group, whereas no difference was detected at 3 and 6 months. Notably, at the later period ( 9 months post-infection), reduced $\mathrm{CD} 3 \zeta$ was associated with elevated ARG-1 expression (Fig. 1a) and a significantly decreased L-arginine concentration in serum (Fig. 5a). At the first 6 months, the degree of
ARG-1 metabolism might be not enough to impair T cell function, which needs further experimental verification. Rodriguez et al. [36] showed that the concentration of L-arginine below $40 \mu \mathrm{M}$ caused a rapid decrease of $\mathrm{CD} 3 \zeta$ chain in vitro, consistent with rodents and patients undergoing trauma or liver transplantation [37, 38]. In vitro, $\mathrm{ARG}-1$, but not $\mathrm{iNOS}$ or $\mathrm{H}_{2} \mathrm{O}_{2}$, produced by E. granulosus-associated peritoneal cells prevented the re-expression of $\mathrm{CD} 3 \zeta$ chain in $\mathrm{CD}^{+}$and $\mathrm{CD}^{+} \mathrm{T}$ cells, 


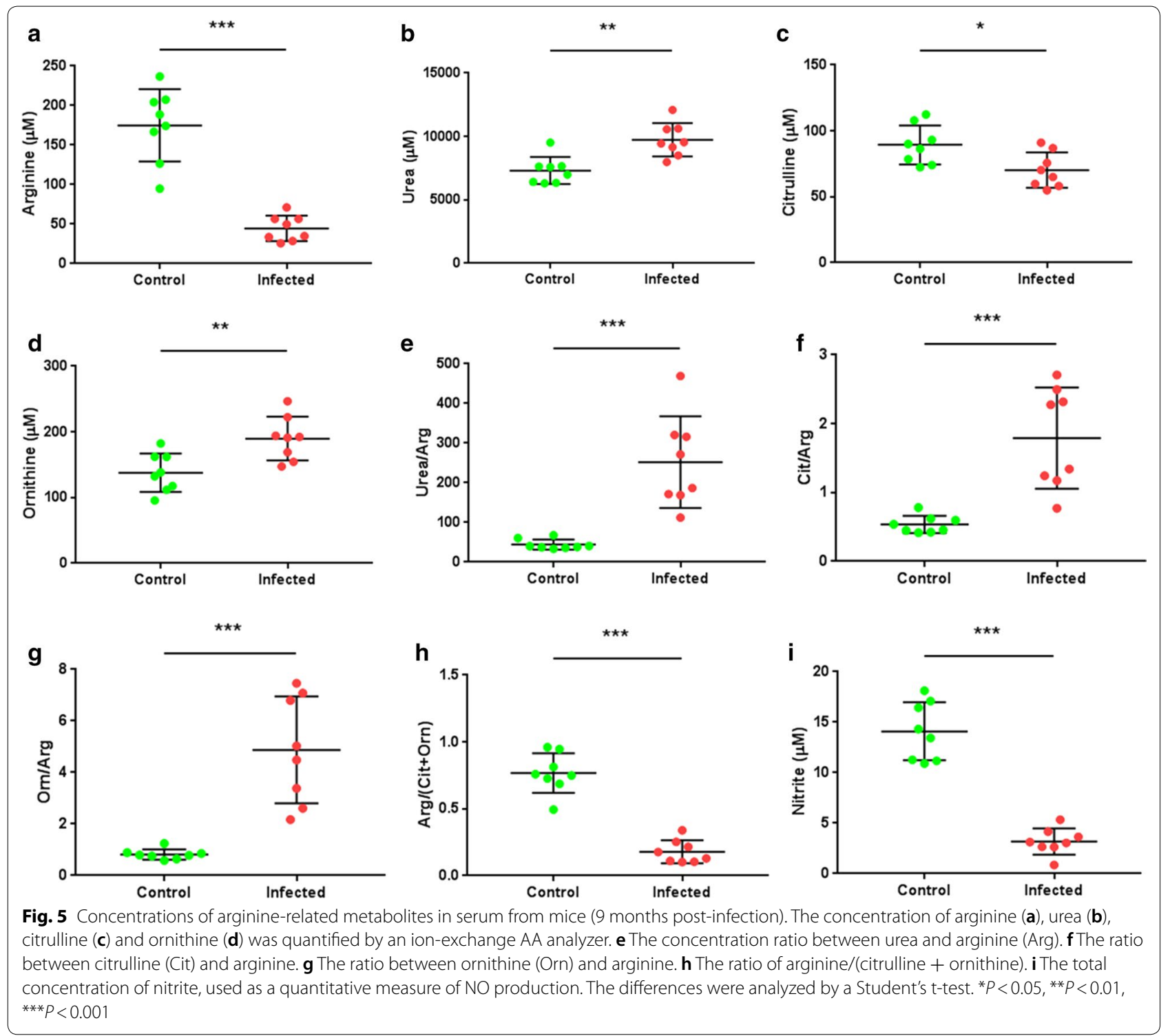

regenerated by the supplement of $\mathrm{L}$-arginine or BEC. The hydrogen peroxide scavenger catalase was included in some experiments because $\mathrm{H}_{2} \mathrm{O}_{2}$ released by activated macrophages and neutrophils has been shown to impair CD3 $\zeta$ expression in previously published reports [39, 40]. A similar effect has been observed in a tumor model, where the addition of exogenous L-arginine or arginase inhibitors could recover the $\mathrm{CD} 3 \zeta$ loss and $\mathrm{T}$ cell proliferation was reestablished [36]. Although the availability of $\mathrm{L}$-arginine influenced $\mathrm{CD} 3 \zeta$ expression and $\mathrm{T}$ cell function, and initial reports suggested that the low expression of $\mathrm{CD} 3 \zeta$ was associated with impaired $\mathrm{T}$ cell function $[41,42]$, the causal relationship between them has not been completely defined and requires further research.
Studies have shown that $\mathrm{T}$ cells also exhibited early activation status marked by CD25, CD69, CD122, CD132 and increased IL-2 production, when cultured in L-arginine-free media [4]. Meanwhile, when such $\mathrm{T}$ cells were stimulated by phorbol myristate acetate, which bypassed $\mathrm{T}$ cell receptor signaling, they also failed to proliferate, meaning some other mechanisms may present in causing $\mathrm{T}$ cell dysfunction triggered by the absence of $\mathrm{L}$-arginine [6].

L-arginine is mainly converted by arginase and NOS to L-ornithine and urea, $\mathrm{NO}$ and L-citrulline, respectively. The defensive role of $\mathrm{NO}$ in the host against E. granulosus larvae was previously reported [43]. In vitro, the laminated layer was found to reduce NO production [44] and 
increase arginase expression [43]. At the later stage of EgPSC infection, in the present study, we found the arginine pathway in serum exhibited more arginase metabolites and less $\mathrm{NO} /$ citrulline in infected mice than those in control mice, indicating that the antagonism of both enzymes is present in E. granulosus-infected mice. The same result appeared in severe fever with thrombocytopenia syndrome (SFTS) cases, where the global arginine bioavailability ratio (GABR) was used as a good prognostic marker for fatal prediction in early SFTS virus infection [45]. Taken together, these results corroborate that $\mathrm{L}$-arginine metabolism postinfection is skewed toward a preferential production of ornithine/urea instead of $\mathrm{NO} /$ citrulline, which is beneficial to parasite survival.

\section{Conclusions}

This study provide important data showing increased expression of ARG-1 in peritoneal cells after Eg-PSC infection. In addition, along with the extension of infection time, the expression of ARG-1 showed a rising trend in multiple myeloid cells, whereas the expression of the $\mathrm{CD} 3 \zeta$ chain showed a decreasing trend. Moreover, the ARG-1 produced by E. granulosus-associated peritoneal cells not only inhibited the re-expression of $\mathrm{CD} 3 \zeta$ by metabolism, but antagonized iNOS. Understanding the underlying mechanism of arginase in immune evasion of E. granulosus infection will pave the way for targeted treatment.

\section{Supplementary information}

Supplementary information accompanies this paper at https://doi. org/10.1186/s13071-020-3919-4.

\section{Additional file 1: Table S1. Primers used in qPCR detection.}

Additional file 2: Figure S1. Immunofluorescent assay of ARG-2 in whole peritoneal cells ( 9 months post-infection). DAPI was used to visualize nuclei.

\section{Abbreviations}

ARG: Arginase; iNOS: Inducible nitric oxide synthase; Eg-PSC: Echinococcus granulosus protoscoleces; PBS: Phosphate-buffered saline; BEC: S-(2boronoethyl)-L-cysteine; L-NMMA: L-monomethyL-L-arginine; DAPI: 4'6-diamidino-2-phenylindole, dihydrochloride; CDNA: Complementary deoxyribonucleic acid; GAPDH: glyceraldehyde-3-phos-phate dehydrogenase; M-MDSCs: Monocytic myeloid-derived suppressor cells; NO: Nitric oxide; ASS: Argininesuccinate synthetase; IL: Interleukin; LPS: Lipopolysaccharide.

\section{Acknowledgements}

We are grateful to Professor Jian Gao (Xinjiang Medical University) for collecting the E. granulosus protoscoleces in Xinjiang Uygur Autonomous Region, China.

\section{Authors' contributions}

JXC and YS conceived the study. SC, WG, YW and YX performed the experiments. XZ and MX performed data analysis. SC wrote the manuscript. JPC and JXC revised the paper. JXC, YS and JPC contributed reagents and materials. All authors read and approved the final manuscript.

\section{Funding}

This study was supported by the National Natural Science Foundation of China (No. 81772224), the National Science and Technology Major Program of China (No. 2018ZX10713001-004), the National Key Research and Development Program of China (No. 2016YFC1 202000 and No. 2016YFC1202001), the Project of Control and Prevention for Echinococcosis, Chinese Center for Disease Control and Prevention, China (No. 131031104000160003). The funders had no role in the study design, data collection and analysis, the decision to publish, or preparation of the manuscript.

\section{Availability of data and materials}

Data supporting the conclusions of this article are included within the article and its additional files.

\section{Ethics approval and consent to participate}

All animal experiments were performed in strict accordance with the Regulations of the Administration of Affairs Concerning Experimental Animals (approved by the State Council of People's Republic of China). Efforts were made to use less mice and minimize suffering. The protocol was approved by the Laboratory Animal Welfare and Ethics Committee (LAWEC), National Institute of Parasitic Diseases, Chinese Center for Disease Control and Prevention, China (Permit Number: IPD-2017-18).

\section{Consent for publication}

Not applicable.

\section{Competing interests}

The authors declare that they have no competing interests.

\section{Author details}

${ }^{1}$ National Institute of Parasitic Diseases, Chinese Center for Disease Control and Prevention, Shanghai 200025, China. ${ }^{2}$ Chinese Center for Tropical Diseases Research, Shanghai 200025, China. ${ }^{3}$ WHO Collaborating Centre for Tropical Diseases, Shanghai 200025, China. ${ }^{4}$ National Center for International Research on Tropical Diseases, Ministry of Science and Technology, Shanghai 200025, China. ${ }^{5}$ Key Laboratory of Parasite and Vector Biology, Ministry of Health, Shanghai 200025, China.

Received: 11 October 2019 Accepted: 29 January 2020

Published online: 06 February 2020

\section{References}

1. Wu GY, Morris SM. Arginine metabolism: nitric oxide and beyond. Biochem J. 1998:336:1-17.

2. Bronte $V$, Zanovello P. Regulation of immune responses by L-arginine metabolism. Nat Rev Immunol. 2005;5:641-54.

3. Taheri F, Ochoa JB, Faghiri Z, Culotta K, Park HJ, Lan MS, et al. L-Arginine regulates the expression of the T-cell receptor zeta chain (CD3zeta) in Jurkat cells. Clin Cancer Res. 2001;7(Suppl. 3):958-65.

4. Zea AH, Rodriguez PC, Culotta KS, Hernandez CP, DeSalvo J, Ochoa JB, et al. L-Arginine modulates CD3 , expression and T cell function in activated human T lymphocytes. Cell Immunol. 2004;232:21-31.

5. Vincendeau P, Gobert AP, Daulouede S, Moynet D, Mossalayi MD. Arginases in parasitic diseases. Trends Parasitol. 2003;19:9-12.

6. Caldwell RW, Rodriguez PC, Toque HA, Narayanan SP, Caldwell RB. Arginase: a multifaceted enzyme important in health and disease. Physiol Rev. 2018;98:641-65.

7. Alderton WK, Cooper CE, Knowles RG. Nitric oxide synthases: structure, function and inhibition. Biochem J. 2001;357:593-615.

8. Bogdan C. Nitric oxide and the immune response. Nat Immunol. 2001;2:907-16.

9. Pesce JT, Ramalingam TR, Mentink-Kane MM, Wilson MS, El Kasmi KC, Smith AM, et al. Arginase-1-expressing macrophages suppress Th2 cytokine-driven inflammation and fibrosis. PLoS Pathog. 2009;5:e1000371.

10. Campbell L, Saville CR, Murray PJ, Cruickshank SM, Hardman MJ. Local arginase 1 activity is required for cutaneous wound healing. J Invest Dermatol. 2013;133:2461-70. 
11. Paduch K, Debus A, Rai B, Schleicher U, Bogdan C. Resolution of cutaneous leishmaniasis and persistence of Leishmania major in the absence of arginase 1. J Immunol. 2019;202:1453-64.

12. Szefel J, Danielak A, Kruszewski WJ. Metabolic pathways of L-arginine and therapeutic consequences in tumors. Adv Med Sci. 2019;64:104-10.

13. Zheng YD. Strategies of Echinococcus species responses to immune attacks: implications for therapeutic tool development. Int Immunopharmacol. 2013;17:495-501.

14. Pan W, Hao WT, Shen YJ, Li XY, Wang YJ, Sun FF, et al. The excretory-secretory products of Echinococcus granulosus protoscoleces directly regulate the differentiation of B10, B17 and Th17 cells. Parasit Vectors. 2017;10:348.

15. Budke CM, Carabin H, Ndimubanzi PC, Nguyen H, Rainwater E, Dickey $M$, et al. A systematic review of the literature on cystic echinococcosis frequency worldwide and its associated clinical manifestations. Am J Trop Med Hyg. 2013;88:1011-27.

16. Amri M, Mezioug D, Touil-Boukoffa C. Involvement of IL-10 and IL-4 in evasion strategies of Echinococcus granulosus to host immune response. Eur Cytokine Netw. 2009;20:63-8.

17. Cao SK, Pan W, Liu H, Cao JP, Shen YJ. Expression and activity of arginase from monocytic-type myeloid-derived suppressor cells in rats infected with Echinococcus granulosus. Chin J Parasitol Parasit Dis. 2016;34:27-31.

18. Peng SS, Yu T, Wang L, Lan X, Wang Q, Jiang T, et al. Influence of type 2 macrophages (M2) in echinococcosis. Int J Clin Exp Pathol. 2016;9:4110-6.

19. Nakao M, Sako Y, Yokoyama N, Fukunaga M, Ito A. Mitochondrial genetic code in cestodes. Mol Biochem Parasitol. 2000;111:415-24.

20. Rodriguez PC, Zea AH, DeSalvo J, Culotta KS, Zabaleta J, Quiceno DG, et al. L-arginine consumption by macrophages modulates the expression of CD3 zeta chain in T lymphocytes. J Immunol. 2003;171:1232-9.

21. Diaz A, Casaravilla C, Allen JE, Sim RB, Ferreira AM. Understanding the laminated layer of larval Echinococcus II: immunology. Trends Parasitol. 2011:27:264-73

22. Paredes R, Godoy P, Rodriguez B, Garcia MP, Cabezon C, Cabrera G, et al. Bovine (Bos taurus) humoral immune response against Echinococcus granulosus and hydatid cyst infertility. J Cell Biochem. 2011;112:189-99.

23. Grubor NM, Jovanova-Nesic KD, Shoenfeld Y. Liver cystic echinococcosis and human host immune and autoimmune follow-up: a review. World $J$ Hepatol. 2017;9:1176-89.

24. El Kasmi KC, Qualls JE, Pesce JT, Smith AM, Thompson RW, Henao-Tamayo $M$, et al. Toll-like receptor-induced arginase 1 in macrophages thwarts effective immunity against intracellular pathogens. Nat Immunol. 2008;9:1399-406.

25. Bowcutt R, Bell LV, Little M, Wilson J, Booth C, Murray PJ, et al. Arginase1-expressing macrophages are dispensable for resistance to infection with the gastrointestinal helminth Trichuris muris. Parasite Immunol. 2011;33:411-20.

26. Munder M, Eichmann K, Morán JM, Centeno F, Soler G, Modolell M. Th1/ Th2-regulated expression of arginase isoforms in murine macrophages and dendritic cells. J Immunol. 1999;163:3771-7.

27. Bronte V, Serafini P, Mazzoni A, Segal DM, Zanovello P. L-arginine metabolism in myeloid cells controls T-lymphocyte functions. Trends Immunol. 2003:24:301-5

28. Oberlies J, Watzl C, Giese T, Luckner C, Kropf P, Muller I, et al. Regulation of NK cell function by human granulocyte arginase. J Immunol. 2009;182:5259-67.

29. Rogan MT. T-cell activity associated with secondary infections and implanted cysts of Echinococcus granulosus in BALB/c mice. Parasite Immunol. 1998:20:527-33.

30. Rigano R, Profumo E, Bruschi F, Carulli G, Azzara A, loppolo S, et al. Modulation of human immune response by Echinococcus granulosus antigen $B$ and its possible role in evading host defenses. Infect Immun. 2001;69:288-96.
31. Rutschman R, Lang R, Hesse M, Ihle JN, Wynn TA, Murray PJ. Cutting edge: Stat6-dependent substrate depletion regulates nitric oxide production. J Immunol. 2001;166:2173-7.

32. Rostami-Rad S, Jafari R, Yousofi Darani H. Th1/Th2-type cytokine profile in C57 black mice inoculated with live Echinococcus granulosus protoscolices. J Infect Public Health. 2018;11:834-9.

33. Stempin CC, Dulgerian LR, Garrido VV, Cerban FM. Arginase in parasitic infections: macrophage activation, immunosuppression, and intracellular signals. J Biomed Biotechnol. 2010;2010:683485.

34. Meurs H, Zaagsma J, Maarsingh H, van Duin M. Recent patents in allergy/ immunology: use of arginase inhibitors in the treatment of asthma and allergic rhinitis. Allergy. 2019;74:1206-8.

35. Ochoa JB, Bernard AC, Mistry SK, Morris SM, Figert PL, Maley ME, et al. Trauma increases extrahepatic arginase activity. Surgery. 2000;127:419-26.

36. Rodriguez PC, Quiceno DG, Zabaleta J, Ortiz B, Zea AH, Piazuelo MB, et al. Arginase I production in the tumor microenvironment by mature myeloid cells inhibits T-cell receptor expression and antigen-specific T-cell responses. Cancer Res. 2004;64:5839-49.

37. Schaffer M, Barbul A. Lymphocyte function in wound healing and following injury. Br J Surg. 1998;85:444-60.

38. Roth E, Steininger R, Winkler S, Langle F, Grunberger T, Fugger R, et al. L-Arginine deficiency after liver transplantation as an effect of arginase efflux from the graft: influence on nitric oxide metabolism. Transplantation. 1994:57:665-9.

39. Otsuji M, Kimura Y, Aoe T, Okamoto Y, Saito T. Oxidative stress by tumorderived macrophages suppresses the expression of CD3 zeta chain of T-cell receptor complex and antigen-specific T-cell responses. Proc Natl Acad Sci USA. 1996;93:13119-24.

40. Schmielau J, Finn OJ. Activated granulocytes and granulocyte-derived hydrogen peroxide are the underlying mechanism of suppression of T-cell function in advanced cancer patients. Cancer Res. 2001;61:4756-60.

41. Barbul A, Rettura G, Levenson SM, Seifter E. Arginine: a thymotropic and wound-healing promoting agent. Surg Forum. 1977;28:101-3.

42. Geiger R, Rieckmann JC, Wolf T, Basso C, Feng YH, Fuhrer T, et al. L-Arginine modulates $T$ cell metabolism and enhances survival and anti-tumor activity. Cell. 2016;167:829-42.

43. Amri M, Touil-Boukoffa C. A protective effect of the laminated layer on Echinococcus granulosus survival dependent on upregulation of host arginase. Acta Trop. 2015;149:186-94.

44. Steers NJ, Rogan MT, Heath S. In vitro susceptibility of hydatid cysts of Echinococcus granulosus to nitric oxide and the effect of the laminated layer on nitric oxide production. Parasite Immunol. 2001;23:411-7.

45. Li XK, Lu QB, Chen WW, Xu W, Liu R, Zhang SF, et al. Arginine deficiency is involved in thrombocytopenia and immunosuppression in severe fever with thrombocytopenia syndrome. Sci Transl Med. 2018;19:10.

\section{Publisher's Note}

Springer Nature remains neutral with regard to jurisdictional claims in published maps and institutional affiliations.
Ready to submit your research? Choose BMC and benefit from:

- fast, convenient online submission

- thorough peer review by experienced researchers in your field

- rapid publication on acceptance

- support for research data, including large and complex data types

- gold Open Access which fosters wider collaboration and increased citations

- maximum visibility for your research: over 100M website views per year

At $\mathrm{BMC}$, research is always in progress.

Learn more biomedcentral.com/submissions 